RESEARCH

\title{
Direct cDNA Selection with DNA Microdissected from Mouse Chromosome 16: Isolation of Novel Clones and Construction of a Partial Transcription Map of the C3-C4 Region
}

\author{
Jianjun Wei, ${ }^{1}$ M.E. Hodes, ${ }^{1,2}$ Yi Wang, ${ }^{1}$ Yue Feng, ${ }^{1}$ \\ Bernardino Ghetti, ${ }^{1,2}$ and Stephen R. Dlouhy ${ }^{1-3}$
}

Departments of ${ }^{1}$ Pathology and Laboratory Medicine and ${ }^{2}$ Medical and Molecular Genetics, Indiana University School of Medicine, Indianapolis, Indiana 46202 USA

A group of cDNA segments was selected by direct hybridization of mouse cerebellar cDNAs against genomic DNA pools generated by microdissection of the mouse chromosome 16 (MMU16) C3-C4 region. After elimination of repetitive sequences and adjustment for redundancy among clones, 34 novel cDNA fragments were isolated. The MMUl6 origin of clones was confirmed by genetic linkage mapping. Reverse transcription PCR indicated that $\sim 68 \%$ of the cDNAs represent transcripts that are expressed in adult mouse cerebellum. Northern blotting showed that some of these are predominantly or solely expressed in brain. This work demonstrates that DNA microdissected from banded MMU16 can be used for direct cDNA selection, thus enabling construction of a new, region-specific partial transcription map. This selected cDNA library should be a useful reagent for further molecular neurobiological studies.

The distal, C3-C4 region of mouse chromosome 16 (MMU16) represents $\sim 1 \%$ of the mouse genome, is estimated to be $20 \mathrm{Mb}$ in physical length and may contain hundreds of genes. This portion of MMU16 is homologous to the portion of the long arm of human chromosome 21 (HSA21) extending from Mx1 to D16H21S16 (Nadeau et al. 1992; Reeves et al. 1993). To date, relatively few genes that are expressed in the central nervous system (CNS) have been isolated from/mapped to this region. Isolation and mapping of such sequences should contribute to our understanding of the involvement of this region in neural development and degeneration.

Construction of transcription maps of genomic regions is of interest and several strategies for accomplishing this have been derived. These include exon trapping (Duyk et al. 1992), searching for hypomethylated GC islands (Bird 1986), screening cDNA libraries with labeled genomic

${ }^{3}$ Corresponding author.

E-MAIL sdlouhy@medgen.iupui.edu; FAX (317) 274-1069.
DNA (Elvin et al. 1990), analysis of genomic DNA for the presence of open reading frames (Fearon et al. 1990) and direct cDNA selection (Lovett et al. 1991). These approaches each require genomic DNA or sequences that represent the region of interest. The genomic materials used for regionspecific searches for expressed sequences are mainly yeast artificial chromosomes (YACs) (Elvin et al. 1990; Snell et al. 1993), cosmids (Lawrence et al. 1994), regional genomic libraries (Bonaldo et al. 1994), and genomic DNA pools from microdissection (Yu et al. 1992). Although microdissection of genomic DNA followed by isolation of region-specific cDNAs appears to have good potential as a simple, straightforward way for the construction of transcription maps and for the identification of candidate genes for genetic disorders, this approach has been reported in a relatively small number of studies (e.g., Buiting et al. 1992; Yu et al. 1992; Su et al. 1994; Yokoi et al. 1994). The yield of cDNA clones from microdissection pools and direct selection is usually lower than from YACs (Rommens et al. 1993; Peterson et al. 1994). This may be because only a portion of the genomic DNA is present in the 
microdissection pool (Yokoi et al. 1994) and relatively short fragments are obtained (Kao 1993). Nevertheless, novel genes can be identified in this manner, and they should be enriched for those that are expressed in the tissues from which the cDNA libraries are derived (Parrish and Nelson 1993). This provides a method for the isolation of region- and tissue-specific expressed sequences.

As part of a positional cloning approach for isolation of the weaver gene (Wei et al. 1994), we have reported the use of microdissection to obtain genomic DNA from the C3-C4 region of MMU16. In the current study we report the utilization of that DNA plus additional microdissected genomic DNA, for direct cDNA selection from cerebellar cDNA. We also partially characterize a number of novel cDNAs that we have obtained and we present a transcription map of our clones in relation to some known MMU16 markers.

\section{RESULTS}

\section{Microdissected Genomic DNA Pools and Cerebellar cDNA Libraries}

Two microdissected genomic DNA pools (A and B) from the MMU16 C3-C4 region were generated by sequence-independent amplification (SIA) in separate experiments. Pool $\mathrm{B}$ has been partially characterized (Wei et al. 1994). Briefly, for pool B, (1) the average size of microdissected genomic DNA fragments is $\sim 550 \mathrm{bp}$, (2) $\sim 80 \%$ of the fragments originate from the microdissected chromosome, (3) $>30 \%$ of the fragments are unique (single-copy) sequence, and (4) genetic linkage analysis has demonstrated that the microdissected genomic DNA fragments cover $\sim 27 \mathrm{cM}$. These findings indicate that the microdissected DNA should be valuable for direct selection of region-specific cDNAs.

Libraries used for direct selection of cDNAs were from newborn mouse $w v /+$ cerebella. One library was unsubtracted and the other was subtracted to enrich for transiently expressed and/or granule cell-related cDNAs (see Methods). Because genes expressed in the cerebellum represent a subset of the genome (Crampton et al. 1981), direct cDNA selection from cerebellar cDNA libraries is expected to yield only a portion of the genes in this region of MMU16. However, this approach provides a means of obtaining genes that may be important in cerebellar pathology.

\section{DIRECT CDNA SELECTION WITH MICRODISSECIED DNA}

\section{cDNA Selection}

The general procedure of direct cDNA selection from pools of microdissected genomic DNA is illustrated in Figure 1. The genomic SIA PCR products of pools A and B were of comparable size. SIA genomic PCR products (250 ng) and $100 \mathrm{ng}$ of control DNA (pBR322) were denatured and immobilized on filter discs. The filters were hybridized with pooled cerebellar cDNA inserts generated from the libraries by PCR with vector primers. To block repetitive elements, $>100$-fold excess of genomic DNA and mouse cot-1 DNA were used during prehybridization and cDNA hybridization/selection. The hybridized cDNAs were eluted, amplified by PCR, and subjected to a second round of cDNA hybridization/selection, elution, and amplification. PCR-amplified cDNA fragments were cloned directly into PCR II. These PCR-based, selected cDNA clones are referred to as PBS (PCR-based screening) clones.

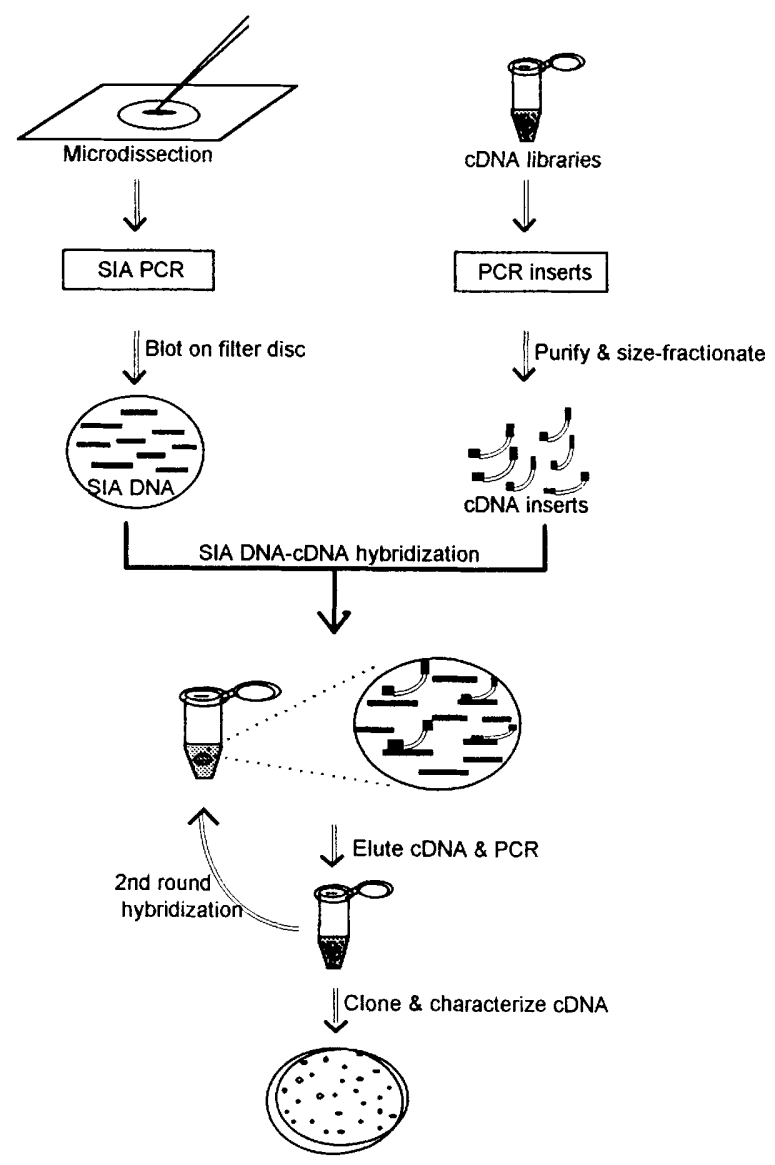

Figure 1 Schematic diagram of direct cDNA selection from microdissection DNA pools (see text for details). 


\section{WEI ET AL.}

\section{Characterization of cDNAs}

In an initial experiment, 96 recombinant clones were picked randomly from the PBS cDNA clones selected with each SIA genomic DNA pool (192 clones total). Inserts (sizes from 97 to $940 \mathrm{bp}$ ) were generated by PCR with vector primers. Southern blot hybridization of inserts with ${ }^{32} \mathrm{P}$ labeled mouse total genomic DNA enabled further separation of unique sequences from repetitive elements. Approximately two-thirds of the inserts showed high or mid-level hybridization with mouse genomic DNA. These clones were considered to be repetitive and were set aside. Sixty-four negative or low-level hybridization clones were collected for further study ( 37 from pool A and 27 from pool B).

To assess preliminarily whether the clones were of chromosome-16 origin, all of the cDNAs were tested by hybridization to genomic DNA from a hamster/mouse hybrid cell line (96Az2; Kozak and Rowe 1980) that contains mouse chromosome 16. Although that cell line is known also to contain a portion of mouse chromosome 15 and the $\mathrm{Y}$ chromosome, this screen provided a means for further selection of clones. Approximately 65\% (42/ 64 ) of the cDNA clones appeared to have uniquesequence inserts that were mapped provisionally to MMU16 (31 clones from pool A and 11 clones from pool B) (Fig 2; Table 1); of the remaining $22 \mathrm{cDNA}$ clones, multiple bands and/or repetitive elements were displayed by $11(-17 \%)$, and the residual 11 $(-17 \%)$ appeared not to be from MMU16. Because pool B contained more repetitive elements and yielded fewer interesting clones than pool A, another 96 pool B-derived clones were screened and an additional 6 clones that mapped provisionally to MMU16 were obtained. For some clones, differences were noted between the mouse-specific bands in the $96 \mathrm{Az} 2$ hybrid cell line DNA and that from mouse genomic DNA. Minor differences in mobility (e.g., PBS4) likely represent lane-related differences, whereas the significant differences in mobility (e.g., PBS3) may represent length polymorphisms. Some clones (e.g., PBS2, PBS37, PBS43) detected additional bands in mouse genomic DNA that were not present in the hybrid. These bands may represent related mouse genes that are not found on chromosome 16 . Some clones detected bands in hamster and/or human genomic DNA (e.g., PBS43, Fig. 2) with varying signal intensities. Thus, by combining screening for repetitive elements and provisional genetic mapping with the somatic cell hybrid, from 288 initial cDNA clones,

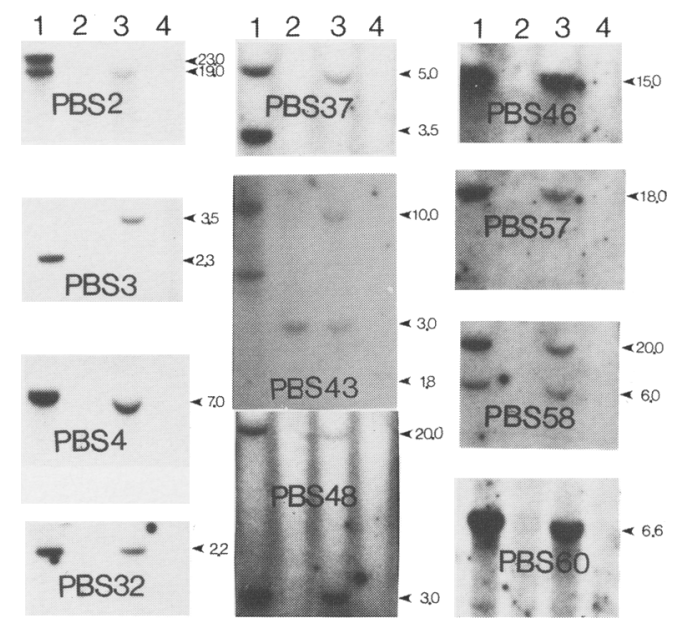

Figure 2 Somatic cell hybrid mapping of selected cDNA clones by Southern blot analysis. The cloned CDNA segments were amplified and used as labeled probes for hybridization to the following DNA: (Lane 1) Mouse; (lane 2) hamster; (lane 3) hamstermouse 96Az2 hybrid cell line (Kozak and Rowe 1980); (lane 4) human. Band sizes (in kb) are indicated to the right of each panel. The PBS43 panel shows an -1.8 -kb human DNA fragment that hybridizes with this PBS clone.

48 putative region-specific cDNAs were selected for further study.

All 48 cDNA segments (insert sizes 143-710 bp) were sequenced partially on both ends and the sequences compared with each other with Microgenie (Queen and Korn 1984). In pool A, six cDNA species were represented more than once, and in pool B one was redundant. In this limited analysis, only one cDNA clone was found to be represented in both pools. A total of 36 distinct sequences were obtained from the 48 cDNA clones. At this time, we cannot rule out the possibility that some of these derived from the same genes. However, because the cDNA libraries used in this study were synthesized with oligo(dT) rather than random primers, the chance of cloning different parts of a single transcript is lessened.

Sequences of the 36 distinct PBS clones were compared with sequences in GenBank. Two clones (PBS17 and PBS43) appeared to represent previously described genes, and the remaining 34 appeared to be novel MMU16-expressed genes. Clone PBS17 contained 226 bp of open reading frame that was identical to a portion of the cDNA for mouse Tiam1 (GenBank accession no. U05245), a gene shown recently to map to MMU16 (Habets et al. 1995). One end of clone 
DIRECT CDNA SELECIION WITH MICRODISSECIED DNA

Table 1. Characterization of cDNA Segments Selected with Microdissected Genomic DNA

\begin{tabular}{|c|c|c|c|c|c|c|c|c|}
\hline $\begin{array}{l}\text { Clone } \\
\text { Name }\end{array}$ & $\begin{array}{l}\text { Locus } \\
\text { Symbol }^{A}\end{array}$ & $\begin{array}{l}\text { Size } \\
(b p)\end{array}$ & $\begin{array}{l}\text { RT- } \\
\text { PCR }^{B}\end{array}$ & $\begin{array}{l}\text { Linkage } \\
\text { Mapped }^{c}\end{array}$ & Primers (5' - & Reverse & $\begin{array}{l}\text { PCR }^{D} \\
\text { (bp) }\end{array}$ & $\begin{array}{l}\text { Access. } \\
\text { Num. }\end{array}$ \\
\hline PBS2 & D16Ium4 & 430 & + & + & AGATTGCTCCTTCCAAGACA & GGCCACAGTTCAAAACACTA & 225 & U23049 \\
\hline PBS3 & D16Ium5 & 580 & $+^{H}$ & + & AAGTGAATTAAGAATTGGAATCA & AGGAAGACTACTGACAGTATT & 117 & $\mathrm{U} 23050$ \\
\hline PBS4 & DI6Ium6 & 450 & + & + & TCCAGTCAGTTTGAGTTGAG & CATAATATCAGGTGAGAGGC & 117 & $\mathrm{U} 23051$ \\
\hline PBS6 & Dl6lum 7 & 144 & nt & NP & TTCAAGGATCTACCTCTGGT & TAGGAGACTTAGCCTACTGA & 124 & $\mathrm{U} 25038$ \\
\hline PBS13 & D16Ium8 & 416 & + & + & GTCATTAAGCAAAACCCTGC & CTTTCTAACACTTGGGAAGC & 233 & U25039 \\
\hline PBS 16 & DI6Ium9 & 700 & + & + & GCTGGAGCCATGGAAGATTCCA & ATTCATCTGTCCTGTTGATGAGAC & 126 & U34396 \\
\hline $\operatorname{PBS} 17^{\mathrm{F}}$ & Dl6Ium10 & 710 & + & + & TGATAAGGTGAGGAAGGACATC & CTGACGGGAACGATAAGACATT & 145 & U34397 \\
\hline PBS18 & Dl6lumll & 500 & - & NP & CGGACTCTGTTATTATCGTG & TGTGCTAGCAGGAGAAAATG & 160 & $\mathrm{U} 23209$ \\
\hline PBS29 & D16Ium 12 & 650 & + & + & GTGCAGTGGGTAAAGAAAACAC & CCTAGCTTCTGGGAAGATACAT & 150 & $\mathrm{U} 23865$ \\
\hline PBS107 & D16Ium 13 & 420 & - & $\mathrm{nt}$ & GTAAATACTTCCCAAAATGCTTC & CTAGCTCTGATAACTTGGAAAG & 132 & U24207 \\
\hline PBS109 & Dl6Iuml4 & 630 & - & $\mathrm{nt}$ & GACAGAATCATGATCAGACTT & AAGTTAGTCTCTTACCTACTTC & 130 & U24208 \\
\hline PBS112 & D16luml5 & 450 & - & $\mathrm{nt}$ & GAATACAAGCTTGGGCTGCA & СTTCTCAGTCTTACATGGTCT & 162 & U24209 \\
\hline PBS114 & D16luml6 & 230 & nt & $\mathrm{nt}$ & & & & U24210 \\
\hline PBS121 & D16hum17 & 740 & nt & nt & & & & U24211 \\
\hline PBS123 & D16Ium18 & 370 & + & $\mathrm{nt}$ & TAGTCTGTGTAGTGCCTCTA & GGTCACAAGGTTCACAGTGA & 150 & U24212 \\
\hline PBS31 & Dl6luml9 & 143 & $+{ }^{\mathrm{H}}$ & nt & $\mathrm{C}$ & $\mathrm{G}$ & 140 & 866 \\
\hline PBS32 & DI6lum 20 & 600 & $+{ }^{\mathrm{H}}$ & + & CGACATCTCAGAGGTTTGTA & GAAGAATGAGTAATGTAGGGT & 140 & U25040 \\
\hline PBS33 & DI6Ium21 & 210 & $++^{\mathrm{H}}$ & + & CTCCAGAGACTTGAATACAG & GACAGAGCAGTTAGCTTACA & 180 & U34398 \\
\hline PBS37 & D16Ium22 & 450 & + & + & GGGCAACTTTATAGAATCGG & CTGGGATTATAGGCACAATG & 172 & $\mathrm{U} 23867$ \\
\hline PBS41 & D16lum 23 & 237 & + & + & GGCAAAGAAGTCACCAATGT & GCTCTCATTTACGAAGCAGT & 135 & U23868 \\
\hline PBS43 ${ }^{\mathrm{G}}$ & DI6Ium24 & 700 & + & + & CTATCACCCATTTGCACTAAG & ATTAACCTATGACATCCAGAG & 165 & U24213 \\
\hline PBS45 & D16Ium 25 & 250 & nt & nt & & & & U23869 \\
\hline PBS46 & Dl6Ium26 & 450 & + & NP & GCTCTGACTATGACTTGCAT & AGAGCCTAGCACACTGCAGA & 130 & U23870 \\
\hline PBS49 & D16Ium27 & 400 & + & + & GTGAACAGACAGCAACTTAG & GTCAGTCTTGCTTGAAGTCA & 140 & U23871 \\
\hline PBS51 & D16lum 28 & 246 & - & + & GAAGATCCTGATTCTCAGCT & GGTGTCTGTAAAGACATCCT & 148 & $\mathrm{U} 23872$ \\
\hline PBS54 & D16Ium29 & 400 & + & + & TTATCCCAGGGTGACTGGAT & CACATACAGCCACAGGAAGT & 150 & U23873 \\
\hline PBS57 & Dl6Ium30 & 201 & $\mathrm{nt}$ & $\mathrm{nt}$ & & & & U23874 \\
\hline PBS60 & DI6Ium3I & 400 & + & + & ATGCCTCTGGCTCTTACAATC & ACTATGGCTCAGGGACACTG & 200 & U23875 \\
\hline PBS63 & Dl6lum 32 & 350 & - & + & TGACCTCTGACTATAACTCCT & TCAGTTATTCTTTGCCTTGTC & 153 & U23876 \\
\hline PBS65 & DI6Ium33 & 250 & + & NP & TATCAGAGCCAGACAGTAACT & GCTTAAGAGAAGTGGTGCTG & 160 & U23877 \\
\hline PBS71 & D16Ium34 & 600 & + & + & TGGTGCAAAGTAAATTGGCAGTT & ATGACTTTAAAGCCTTGTACCAG & 154 & U34399 \\
\hline PBS76 & DI6Ium35 & 200 & + & + & CTGTGATCTTCTCAATGATCAG & CTGTCACATGGCAGATGTGAT & 140 & U23878 \\
\hline PBS80 & DI6Ium36 & 410 & + & + & ATCCCCAGAACCTATGAGGA & GTCCCTAGTTATTTTCCAGAC & 200 & U23879 \\
\hline PBS81 & D16lum 37 & 300 & + & NP & GGACAACCACATTGCTAATTC & GTTACATTATGTCACTGCCCT & 160 & U23880 \\
\hline PBS95 & D16Ium38 & 480 & + & + & TGATAAATGCGGACTCAGAAACA & AATTCGTTTGAAGAGGTCTGTT & 125 & U34400 \\
\hline PBS96 & DI6lum39 & 700 & + & + & AAGGGGATAACATTTGAAATGTA & GAAGACAGCCAATGATGCATG & 130 & U23881 \\
\hline
\end{tabular}

Clones in the upper part (PBS2-123) were derived from pool B1 or B2; clones in the lower part (PBS31-96) were derived from pool A (see Methods); for all columns, nt indicates not tested.

${ }^{A}$ D16 designations are used because all clones detect a mouse-specific band on genomic Southern blot analysis with DNA from $96 \mathrm{Az2}$ cell line.

${ }^{B}$ For RT-PCR studies, a single symbol (+ or - ) indicates that a transcript was $(+)$ or was not $(-)$ detected in RNA from adult mouse cerebellum by RT-PCR with both poly(A)RNA and DNase-treated total RNA as templates, whereas a $+{ }^{\mathrm{H}}$ indicates that RT-PCR was positive with poly $(A)$ RNA as template but was negative with DNase-treated total RNA as template (see text).

${ }^{C}(+)$ The clone mapped to MMU16 by linkage analysis; (NP) not polymorphic.

DThe size of the PCR product using this primer set is given in bp.

${ }^{\mathrm{E}}$ Accession numbers for GenBank.

F,G Previously deposited/described sequence (see text).

PBS43 was identical to a portion of mouse glutamate receptor (Grik1, previously designated Glur5). Grik1 has been mapped to MMU16 at 57.9 cM (closely linked with D16Mit94) (Gregor et al. 1993). PBS43 maps to the same area as Grik1 (see below); thus, it is likely that PBS43 represents Grik1 and that the nonhomologous portion of the clone represents unprocessed intron or an alternative transcript. This has not been pursued further. Some of the clones showed varying degrees of sequence homology to a number of genes or gene fragments from several different species; however, the homologous stretch involved only a small portion of the PBS clone. Four PBS clones (PBS4, 33, 112, 123) showed no homology to any sequence in GenBank. The putative novel PBS cDNA segments have been submitted to GenBank (accession numbers are listed in Table 1). 
WEI EI AL.

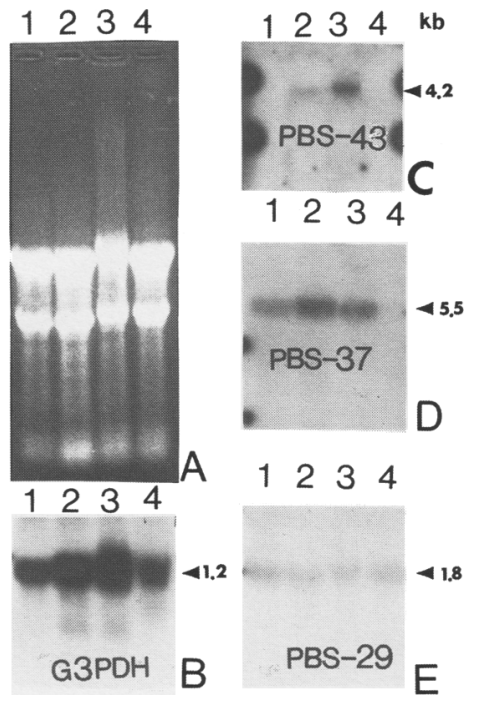

Figure 3 Northern blotting analyses of some PBS CDNA clones. Total RNA $(20 \mu \mathrm{g})$ from mouse liver (lane 1), brain (lane 2), cerebellum (lane 3), and testis (lane 4 ) was separated in a $1.0 \%$ formaldehyde gel $(A)$ and hybridized with control CDNA G3PDH (B) and selected cDNAs PBS-43 (C), PBS-37 $(D)$, and PBS-29 $(E)$. Band sizes (in $\mathrm{kb}$ ) are indicated to the right of each panel.

\section{Expression Analysis}

Primer pairs were made from 31 PBS cDNA segments and were utilized for reverse transcrption (RT)-PCR analyses with mRNA [poly $\left.\left(\mathrm{A}^{+}\right)\right]$and with DNase-treated total RNA from adult mouse cerebella. Twenty-one of these primer pairs $(\sim 68 \%)$ gave positive results in a 40 -cycle PCR reaction with both RNA templates (Table 1). Three additional clones gave positive RT-PCR results with mRNA but not with DNase-treated total RNA, and 10 clones were negative with both RNA sources. Negative RT-PCR results with adult cerebellar mRNA as template may indicate that the corresponding mRNAs are expressed at very low levels or are regulated developmentally. Northern blotting analyses were conducted on selected clones with total RNA $(20 \mu \mathrm{g})$ from several adult mouse tissues, including frontal cortex, cerebellum, liver, and testis, to assess the distribution of expression and to determine transcript size. As illustrated in Figure 3, PBS29 (650-bp insert) detected a 1.8 -kb transcript that was expressed similarly in all tissues tested. PBS37 (450bp insert) detected a 5.5-kb transcript expressed in brain, cerebellum, and liver but not in testis. PBS43 (Grik1, 700-bp insert) detected a 4.2-kb transcript that was expressed highly in mouse cerebellum, as expected for Grik1. In addition to PBS29, 37, and 43, seven other clones (PBS2, 16, $17,33,51,60$, and 96) appeared to detect transcripts in adult cerebellum after Northern blotting, whereas clones PBS3, 4, 6, 13, 18, 31, 32, 41, $46,49,54,63,65,71,76,80,81$, and 95 gave negative results (the other PBS clones were not evaluated by Northern blot). One clone, PBS51, was negative by RT-PCR but detected a smear on a Northern blot, the latter probably attributable to the fact that the clone contains a trinucleotide repeat. Of the Northern blot-positive clones (excluding PBS51), zoo blot analysis (mouse, rat, hamster, dog, pig, and human genomic DNA) indicates that PBS16, 17, 29, 33, 37, and 43 probably have homologs in other species (not shown). Clones that gave positive results with RT-PCR with both RNA templates but did not detect bands on Northern blotting (e.g., PBS4) may represent transcripts of low-copy number.

\section{Genetic Mapping}

All clones that were carried to this stage of the analysis had already been mapped provisionally to MMU16 by the Southern blotting analysis described above with DNA from a mouse/hamster hybrid cell line, as we had done in our initial study of microdissected SIA genomic clones (Wei et al. 1994). We then sought to map the PBS cDNA clones by genetic linkage analysis. Primer sets were made for selected clones, and the fragments generated were utilized for single-strand conformational polymorphism (SSCP) analysis. Polymorphisms that were detected (e.g., Fig. 4) were used for linkage analysis with 94 progeny of

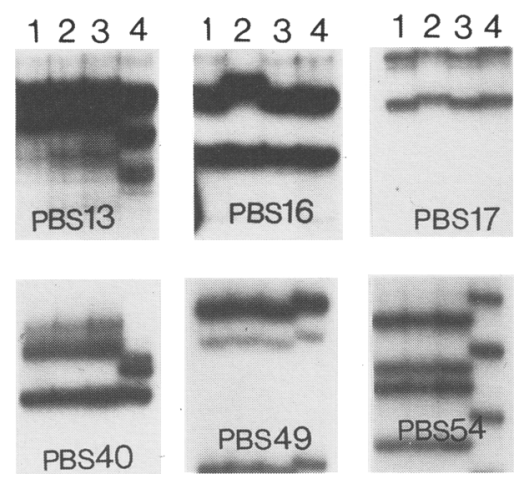

Figure 4 Single-strand conformational polymorphisms for selected $\mathrm{PBS}$ clones in mouse strains $\mathrm{BALB} / \mathrm{CJ}$ (lane 1), CBA/J (lane 2), C57BL/6J (lane 3) and $M$. spretus (lane 4). Clone names are indicated. PBS40 = PBS4 (redundant clones). 


\section{DIRECT CDNA SELECTION WITH MICRODISSECTED DNA}

a $(\mathrm{C} 57 \mathrm{BL} / 6 \mathrm{~J} \times$ Mus spretus $) \times M$. spretus backcross panel (from Jackson Laboratories) and/or with 192 progeny of a $(\mathrm{BALB} / \mathrm{cJ} \times \mathrm{CBA} /$ J) $\times \mathrm{CBA} / \mathrm{J}$ backcross panel (from our colony). Some primer sets yielded weak or no amplification with $M$. spretus DNA, suggesting sequence divergence at one or both primer sites. Of $28 \mathrm{PBS}$ clones tested, 22 were polymorphic and all were mapped genetically to distal MMU16 with the Jackson Laboratory panel. The second mapping panel was used to obtain more precise localization for clones PBS17, PBS16, and PBS33. The gene order and distances in relation to reference markers are illustrated in Figure 5. Primer sequences and PCR product sizes are indicated in Table 1.

\section{DISCUSSION}

Relatively few genes have been identified on distal MMU16, and many of these identifications

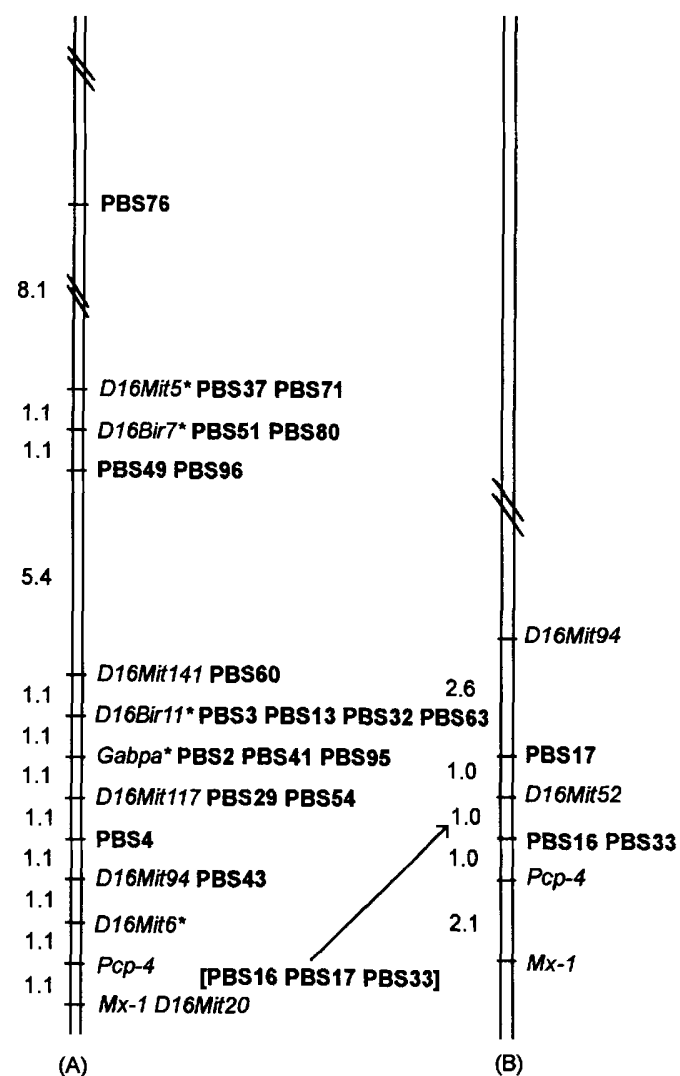

Figure 5 Genetic linkage mapping of selected PBS cDNAs on distal MMU16. Approximate distances (in $\mathrm{CM}$ at left) were determined from analysis of results of The Jackson Laboratory $(\mathrm{C} 57 \mathrm{BL} / 6) \times M$. spretus $) \times M$. spretus backcross panel $(A)$ and our own $[(B A L B / C] \times C B A / J) \times C B A / J]$ backcross panel (B). are based on homology to human sequences (Reeves et al. 1993). This region is homologous to a portion of human chromosome 21 (HSA21) that has been studied in considerable detail (e.g., Rommens et al. 1993; Dufresne-Zacharia et al. 1994; Patil et al. 1994; Wang and Smith 1994). Because distal MMU16 is likely to express multiple genes, some of which may be unique to or more highly expressed in mice, it is important to isolate region-specific expressed sequences by the utilization of mouse materials.

In this study we wished to determine whether the genomic DNA from microdissection of the MMU16 C3-C4 region could serve as a resource for recovery of region-specific cDNAs. cDNA was selected directly with genomic DNA bound to filters, rather than by first isolating unique-sequence genomic DNA and using it as probe, as has been done by a number of other workers (Buiting et al. 1992; Yu et al. 1992; Yokoi et al. 1994). In the latter approach, the majority of such genomic sequences, although useful as markers, might be expected to represent noncoding DNA. For example, the studies by $\mathrm{Yu}$ et al. (1992), Kao et al. (1994), and Yokoi et al. (1994) each utilized 1000 unique-sequence microdissected clones (in pools) to probe cDNA libraries and recovered 9-12 distinct cDNAs. Our protocol (through the point of cDNA selection) mimics more closely the direct-selection approach of Su et al. (1994), who isolated human region-specific cDNAs from chromosome $12 \mathrm{q} 13$. However, we utilized a lesser amount of microdissected DNA to select from ( $250 \mathrm{ng}$ vs. $60 \mu \mathrm{g}$ ), we blocked with Cot-1 and genomic DNA rather than with just Cot-1 DNA, and we did not include total RNA to capture additional cDNAs via DNA-RNA-cDNA hybrids. Based on analysis of a limited number of clones, this direct-selection method was quite successful. Starting from 288 directly selected recombinant clones, we were able to isolate 34 novel cDNAs that mapped provisionally to MMU16. These findings demonstrate that the strategy of direct cDNA selection with microdissected DNA pools can generate a collection of MMU16, region-specific cDNAs without first requiring tedious genetic and physical mapping.

The microdissected DNA pools, even when combined, probably do not contain all of the genomic DNA of the dissected region. For this reason, and because cDNA from only one tissue (mouse cerebellum) was used and only a limited number of clones were analyzed, the cDNAs reported in this study probably represent just a 


\section{WEI ET AL.}

fraction of the genes expressed in this region of MMU16. For example, Peterson et al. (1994), with YACs as the source of genomic DNA, recovered $>50$ human fetal-brain cDNA fragments encoded by a $1.2-\mathrm{Mb}$ region of human chromosome 21 that is homologous to the MMU16 C4 region (Davisson et al. 1993; Sinet et al. 1993). If we analyzed more clones from our selected cDNAs, we would probably isolate additional novel clones. Southern analyses also showed that some PBS clones may be conserved across species, whereas some may be mouse-specific.

Preliminary studies had indicated that our libraries used as sources of cDNA for selection contained repetitive elements [e.g., somewhat surprisingly, elements with homology to L1 (Schaal et al. 1987) appeared (based on colony hybridization) to represent $\sim 8 \%$ of the unsubtracted cerebellar cDNA library]. Although efforts were made to reduce the recovery of such repetitive sequences, a major problem encountered was that many of the selected cDNAs are/contain repetitive elements, despite efforts (e.g., blocking with Cot-1 and genomic DNA) to reduce the recovery of such elements. The reason for this is unknown. About $70 \%$ of the unique sequence clones map provisionally to the dissected chromosome as determined by hybridization to DNA from a mouse/hamster hybrid cell line that contains MMU16. The cDNA clones that do not map to MMU16 may have been isolated as a result of nonspecific hybridization during the process of cDNA selection or may represent contamination during microdissection.

All PBS cDNAs that were mapped genetically (by SSCP polymorphisms) were localized to distal MMU16, thus confirming the specificity of the approach. Those cDNAs map to 13 different positions. It is likely that some of the clones not yet mapped reside at still different map positions. At this time it is not possible to determine unequivocally how many different genes are represented by the PBS clones; however, with some admittedly simplistic assumptions, it is possible to arrive at an estimate of gene number. Each different map position may represent a different gene. If two clones map to the same position but appear to differ in expression (e.g., Northern blotting results for PBS37 vs. PBS71, RT-PCR results for PBS51 vs. PBS80), the clones also may represent different genes. Utilizing these criteria, of the 22 mapped clones, only PBS3 versus PBS32 and PBS 41 versus PBS95 cannot be distinguished (e.g., Table 1; Fig. 5). Those four clones may rep- resent only two genes. The remaining mapped clones appear to be distinguishable. Thus, in summary, at least 20 different genes may be represented by the PBS clones.

\section{METHODS}

\section{SIA DNA Pools from Microdissection}

Detailed procedures for chromosome microdissection, DNA amplification, and cloning have been described (Bohlander et al. 1992; Wei et al. 1994). In brief, fragments microdissected from the distal (C3-C4) portion of GTGbanded mouse chromosome 16 were amplified by sequence-independent amplification (Bohlander et al. 1992), the initial PCR products (referred to as pool B) were aliquoted and a portion analyzed by fluorescent in situ hybridization (FISH) to mouse chromosomes, and another portion was cloned in PCR II. This was followed by a series of analyses to identify repetitive and unique sequences (by colony hybridization) and to map the clones back to chromosome 16 by Southern blotting analysis of DNA from a somatic cell hybrid and by genetic linkage analysis. The mapping confirmed the region specificity of the pool B genomic library. Another microdissected PCR-amplified DNA pool (pool A) from the same chromosomal region was not cloned, but an aliquot was analyzed by FISH. DNA was purified separately from an aliquot of each pool by phenol/chloroform extraction and Microcon-30 (Amicon) filtration and bound to filter discs as target genomic DNA for direct cDNA selection (see below).

\section{cDNA Pools from Mouse Cerebellum}

Two mouse cerebellar cDNA libraries [poly(A), oligo(dT)primed, $\lambda \mathrm{Gem}$-2] (Hodes et al. 1994) were combined for this study. One library was from newborn $w v /+$ mice. The second library was a subtracted cDNA library that was produced from the newborn library so as to enrich for rare and transiently expressed cDNAs (i.e., by using driver RNA from a P31 $w v / w v$ cerebellar vermis cDNA library). cDNA inserts were generated by PCR amplification of $\sim 2 \times 10^{8}$ clones from a library of $5 \times 10^{6}$ recombinants ( 35 cycles, T7 and Sp6 primers, Stratagene). Approximately $3 \mu \mathrm{g}$ of cDNA insert was produced from each library (average insert length $-1.2 \mathrm{~kb}$ ). The cDNA PCR products were subjected to phenol/chloroform extraction and purified with Microcon-30 filters.

\section{Selection of cDNAs by Hybridization with Filter-bound Genomic DNA}

The general procedure followed was that of Lovett et al. (1991), with modifications to fit our materials and to increase sensitivity and simplify the procedure. Briefly, $\sim 250$ ng of purified genomic SIA PCR products (average length of $550 \mathrm{bp}$ ) from each pool, $\mathrm{A}$ and $\mathrm{B}$, was denatured, neutralized, and blotted onto 5-mm Nytran-plus filter discs. Control discs contained $100 \mathrm{ng}$ of linearized, denatured pBR322 DNA. The discs were prehybridized in sodium 


\section{DIRECT CDNA SELECTION WITH MICRODISSECTED DNA}

phosphate buffer $\left(25 \mathrm{mM} \mathrm{Na}_{2} \mathrm{HPO}_{4} / \mathrm{NaH}_{2} \mathrm{PO}_{4}\right.$ at pH 7.0, $7 \%$ SDS) and blocked with denatured sheared mouse genomic DNA $(50 \mu \mathrm{g} / \mathrm{ml})$ and mouse Cot-1 DNA $(30 \mu \mathrm{g} / \mathrm{ml}$, GIBCO BRL) in a total volume of $2 \mathrm{ml}$ at $65^{\circ} \mathrm{C}$ for $5 \mathrm{hr}$. To block the cDNA probe prior to its use for filter hybridization, $500 \mathrm{ng}$ of cDNA was coprecipitated with $50 \mu \mathrm{g}$ of sheared mouse genomic DNA (average length, $500 \mathrm{bp}$ ) and $5 \mu \mathrm{g}$ of mouse Cot-1 DNA, denatured, and incubated for 2 hr at $65^{\circ} \mathrm{C}$ in a total volume of $100 \mu \mathrm{l}\left(25 \mathrm{~mm} \mathrm{NaHPO}_{4}\right.$ at $\mathrm{pH}$ 7.0). Hybridization was carried out at $65^{\circ} \mathrm{C}$ for $24 \mathrm{hr}$ in $1 \mathrm{ml}$ of prehybridization solution. After hybridization, filters were washed once with $2 \times \mathrm{SSC} / 0.5 \%$ SDS and four times with $0.1 \times \mathrm{SSC} / 0.1 \% \mathrm{SDS}$ at $65^{\circ} \mathrm{C}$ for a total of $4 \mathrm{hr}$.

\section{Elution, PCR, and Cloning of the Selected cDNAs}

The hybridized cDNAs were eluted from discs with $50 \mu$ l of $50 \mathrm{~mm} \mathrm{NaOH}$ at room temperature for $15 \mathrm{~min}$ followed by neutralization with $50 \mu \mathrm{l}$ of $1 \mathrm{~m}$ Tris- $\mathrm{HCl}(\mathrm{pH} \mathrm{7.6)}$. The eluted cDNA was purified by passage through a G-50 column and concentrated to $20 \mu \mathrm{l}$. Five microliters of the purified CDNA was used as template in a $50-\mu l$ PCR reaction [vector primers $\mathrm{T} 7$ and $\mathrm{Sp} 6$, denaturation $2 \mathrm{~min}$ $\left(94^{\circ} \mathrm{C}\right)$ followed by 35 amplification cycles $\left(30 \mathrm{sec}\right.$ at $94^{\circ} \mathrm{C}$, $30 \mathrm{sec}$ at $54^{\circ} \mathrm{C}, 90 \mathrm{sec}$ at $72^{\circ} \mathrm{C}$ ), Perkin-Elmer 9600 thermocycler, Boehringer Mannheim PCR kit]. Five microliters of PCR product was evaluated by electrophoresis in a $1.5 \%$ agrose gel, and the remaining DNA was purified and subjected to a second round of selected hybridization with a new pool A or pool B genomic DNA filter disc.

After cDNA elution and amplification, $2 \mu \mathrm{l}$ of PCR product ( $20 \mathrm{ng}$ of DNA) from second-round hybridization selection was cloned in PCR II following the manufacturer's instructions (Invitrogen). Ninety-six white colonies were picked randomly, and the cells were lysed in $30 \mu \mathrm{l}$ of lysis buffer $(1 \times \mathrm{TE}$ at $\mathrm{pH} 8.0$ containing $1 \%$ Triton $\mathrm{X}-100)$ at $98^{\circ} \mathrm{C}$ for $10 \mathrm{~min}$. Two microliters of lysed cells was used for 15- $\mu$ l PCR reactions with M13 reverse and forward primer pairs to generate individual cDNA inserts. Five microliters of PCR product was separated on a $1.5 \%$ agarose gel to check insert sizes. The gel was blotted onto Nytranplus (Schleicher \& Schuell).

\section{Southern Blot Hybridization for Preliminary Mapping}

After electrophoretic separation, filters containing the cDNA inserts were hybridized with ${ }^{32} \mathrm{P}$-labeled mouse genomic DNA to identify unique and repetitive sequences. The nonhybridizing (negative) clones were used as probes for Southern hybridization with EcoRI-digested genomic DNA from mouse, hamster, human, and mouse/hamster hybrid cell line that contains mouse chromosome 16 (Kozak and Rowe 1980). Those clones that hybridized to a mouse-specific band were provisionally considered to be of MMU16 origin (Wei et al. 1994). Final posthybridization wash was with $0.5-2 \times \operatorname{SSC}\left(65^{\circ} \mathrm{C}\right)$.

\section{RT-PCR and Northern Blot Analyses}

cDNA was reverse transcribed with the Marathon cDNA synthesis kit (Clontech) with mRNA isolated from adult mouse cerebellum. Two nanograms of the resulting cDNA was subjected to PCR amplification $25-\mu$ l reaction, $0.5 \mu \mathrm{M}$ primer pairs, $200 \mu \mathrm{M}$ dNTP, 0.2 units of Taq polymerase (Boehringer Mannheim), denaturation at $94^{\circ} \mathrm{C}$ for $2 \mathrm{~min}$, followed by 40 cycles of $94^{\circ} \mathrm{C}(30 \mathrm{sec}), 56^{\circ} \mathrm{C}-60^{\circ} \mathrm{C}(30 \mathrm{sec})$, and $72^{\circ} \mathrm{C}(1 \mathrm{~min})$. PCR products $(10 \mu \mathrm{l})$ were evaluated on a $1.5 \%$ agrose gel. For some analyses (see text), prior to RT-PCR, total RNA (extracted by the method of Chomczynski and Sacchi 1987) was treated with RNase-free DNase I (Ambion, $2 \mathrm{U} /(\mu \mathrm{l})$ at $37^{\circ} \mathrm{C}$ for $30 \mathrm{~min}$, followed by phenol extraction.

For Northern blot analysis, total RNA from mouse brain, cerebellum, liver, and testis was extracted by the method of Chomczynski and Sacchi (1987), and $20 \mu \mathrm{g}$ was separated electrophoretically and moved to Nytran plus membrane by downward alkaline transfer (Chomczynski 1992; Löw and Rausch 1994). Hybridization with randomprimed, ${ }^{32}$ P-labeled cDNA inserts was the same as for Southern blotting described above. Final posthybridization wash was with $0.5 \times \operatorname{SSC}\left(65^{\circ} \mathrm{C}\right)$. Filters were exposed to film at $-70^{\circ} \mathrm{C}$ for $2-7$ days.

\section{DNA Sequencing}

CDNA inserts were generated by PCR with vector-specific primers and, after electrophoretic separation, were purified with a QIAquick gel extraction kit (Qiagen) according to manufacturer's protocols. cDNAs were directly sequenced with a SequiTherm Cycle Sequencing kit (Epicentre Technologies). Sequences were sent to GenBank to search for homologous sequences by the BLASTN program (Altschul et al. 1990).

\section{SSCP Analysis and Genetic Mapping}

Primer sets for SSCP analysis were determined from the DNA sequences, and oligonucleotides were synthesized in our laboratory (Beckman Oligo 1000) or obtained commercially (ONLY DNA). SSCP polymorphisms were resolved with a sequencing gel apparatus and bands visualized by autoradiography following standard protocols (Beier 1993). Briefly, after amplification in the presence of labeled nucleotides, $5-\mu \mathrm{l}$ aliquots of PCR products from individual mice of the parental mouse strains and backcross progeny were mixed with $25-30 \mu l$ of loading buffer (96\% formamide), denatured at $98^{\circ} \mathrm{C}$, and samples were separated by electrophoresis in $5 \%$ acrylamide/ $0.5 \times \mathrm{TBE}$ at $30 \mathrm{~W}$ constant power for $3-4 \mathrm{hr}$ at $4^{\circ} \mathrm{C}$ or at room temperature in $5 \%$ acrylamide containing $5 \%$ glycerol. A (C57 $\mathrm{BL} / 6 \mathrm{~J} \times$ M. spretus) $\times$ M. spretus (Rowe et al. 1994) mapping panel consisting of DNA from 94 backcross offspring was provided by The Jackson Laboratory Backcross DNA Panel Map Service. That service also provided genetic analysis of the data. A second panel $(\mathrm{BALB} / \mathrm{cJ} \times \mathrm{CBA} / \mathrm{J})$ $\times \mathrm{CBA} / \mathrm{J}$ consisting of 192 backcross progeny was produced in our mouse colony. Several gene markers (Reeves et al. 1993) and microsatellite markers (Dietrich et al. 1994) from distal MMU16 were used as reference markers. Gene order was determined so as to minimize the frequency of double crossovers.

\section{ACKNOWLEDGMENTS}

We are grateful to Lucy Rowe and Mary Barter of the Jackson Laboratory for providing the mouse backcross panel 


\section{WEI EI AL.}

and processing genetic linkage data. We thank Lillian Fitzpatrick, Carmen Stauss, and Debbie Lucas for their efforts with our mouse colony. The mouse/hamster hybrid cell line (96Az2) was provided by Dr. Christine Kozak. This work was supported by U.S. Public Health Service grants P01 NS27613 and R01 NS14426. The sequence data described in this paper have been submitted to the GenBank data library under accession numbers U23049-U23051, U23209, U23865-U23881, U24207-U24213, U25038U25040, U34396-U34399, and U34440, as listed in Table 1.

The publication costs of this article were defrayed in part by payment of page charges. This article must therefore be hereby marked "advertisement" in accordance with 18 USC section 1734 solely to indicate this fact.

\section{REFERENCES}

Altschul, S.F., W. Gish, W. Miller, E.W. Myers, and D.J. Lipman. 1990. Basic local alignment search tool. J. Mol. Biol. 215: 403-410.

Beier, D.R. 1993. Single-strand conformation polymorphism (SSCP) analysis as a tool for genetic mapping. Mamm. Genome 4: 627-631.

Bird, A.P. 1986. CpG-rich islands and the function of DNA methylation. Nature 321: 209-213.

Bohlander, S.K., R. Espinosa III, M.M. Le-Beau, J.D. Rowley, and M.O. Diaz. 1992. A method for the rapid sequence-independent amplification of microdissected chromosome material. Genomics 13: 1322-1324.

Bonaldo, M.F., M.-T. Yu, P. Jelenc, S. Brown, L. Su, L. Lawton, L. Deaven, A. Efstratiadis, A. Warburton, and B.M. Soares. 1994. Selection of cDNAs using chromosome-specific genomic clones: Application to human chromosome 13. Hum. Mol. Genet. 3: 1663-1673.

Buiting, K., V. Greger, B.H. Brownstein, R.M. Mohr, I. Voiculescu, A. Vinterpacht, B. Zabel, and B. Horsthemke. 1992. A putative gene family in 15q11-13 and 16p11.2: Possible implication for Prader-Willi and Angelman syndromes. Proc. Natl. Acad. Sci. 89: 5457-5461.

Chomczynski, P. 1992. One-hour downward alkaline capillary transfer for blotting of DNA and RNA. Anal. Biochem. 201: 134-139.

Chomczynski, P. and N. Sacchi. 1987. Single-step method of RNA isolation by acid guanidinium thiocyanate-phenol-chloroform extraction. Anal. Biochem. 162: 156-159.

Crampton, M.J., K.E. Davies, and T.F. Knapp. 1981. The occurrence of families of repetitive sequences in a library of cloned cDNA from human lymphocytes. Nucleic Acid Res. 9: 3821-3834.

Davisson, M.T., C. Schmidt, R.H. Reeves, N.G. Irving, E.C. Akeson, B.S. Harris, and R.T. Bronson. 1993. Segmental trisomy as a mouse model for Down syndrome. Prog. Clin. Biol. Res. 384: 117-133.
Dietrich, W.F., J.C. Miller, R.G. Steen, M. Merchant, D. Damron, R. Nahf, A. Gross, D.C. Joyce, M. Wessel, R.D. Dredge, A. Marquis, L.D. Stein, N. Goodman, D.C. Page, and E.S. Lander. 1994. A genetic map of the mouse with 4,006 simple sequence length polymorphisms. Nature Genet. 7: 220-245.

Dufresne-Zacharia, M.-C., N. Dahmane, D. Theophile, R. Orti, Z. Chettouh, P.-M. Sinet, and J.-M. Delabar. 1994. 3.6-Mb genomic and YAC physical map of the Down syndrome chromosome region on chromsome 21 . Genomics 19: 462-469.

Duyk, G.M., S. Kim, R.M. Myers, and D.R. Cox. 1990. Exon trapping: A genetic screen to identify candidate transcribed sequences in cloned mammalian genomic DNA. Proc. Natl. Acad. Sci. 87: 8995-8999.

Elvin, P., G. Slynn, D. Black, A. Graham, R. Butler, J. Riley, R. Anand, and A.F. Markham. 1990. Isolation of cDNA clones using yeast artificial chromosome probes. Nucleic Acids Res. 18: 3913-3917.

Fearon, E.R., K.R. Cho, J.M. Nigro, S.E. Kern, J.W. Simons, J.M. Ruppert, S.R. Hamilton, A.C. Preisinger, G. Thomas, K.W. Kinzler, and B. Vogelstein. 1990. Identification of a chromosome $18 \mathrm{q}$ gene that is altered in colorectal cancers. Science 247: 49-56.

Gregor, P., R.H. Reeves, E.W. Jabs, X. Yang, W. Dackowski, J.M. Rochelle, R.H. Brown Jr., J.L. Haines, B.F. O'Hara, G.R. Uhl, and M.F. Seldin. 1993. Chromosomal localization of glutamate receptor genes: Relationship to familial amyotrophic lateral sclerosis and other neurological disorders of mice and humans. Proc. Natl. Acad. Sci. 90: 3053-3057.

Habets, G.G.M., R.A Van der Kammen, N.A. Jenkins, D.J. Gilbert, N.G. Copeland, A. Hagemeijer, and J.G. Collard. 1995. The invasion-inducing TIAM1 gene maps to human chromosome band 21q22 and mouse chromosome 16. Cytogenet. Cell Genet. 70: 48-51.

Hodes, M.E., S.R. Dlouhy, J.J. Wei, Y. Wang, L. Sangameswaran, V. Lazar, L.C. Triarhou, and B. Ghetti. 1994. cDNA approaches to isolation of the mouse mutant weaver gene. Neurochem. Res. 19: 1359-1362.

Kao, F.T. 1993. Microdissection and microcloning of human chromosome regions in genome and genetic disease analysis. BioEssays 15: 141-146.

Kao, F.T., J. Yu, S. Tong, J. Qi, S.R. Patanjali, S.M. Weissman, and D. Patterson. 1994. Isolation and refined regional mapping of expressed sequences from human chromosome 21. Genomics 23: 700-703.

Kozak, C.A. and W.P. Rowe. 1980. Genetic mapping of the ecotropic virus-inducing locus $A k v-2$ of the AKR mouse. J. Exp. Med. 152: 1419-1423.

Lawrence, B.J., W. Schwabe, P. Kioschis, J.F. Coy, A. Poustka, M.B. Brennan, and U. Hochageschwender. 


\section{DIRECI CDNA SELECTION WITH MICRODISSECTED DNA}

1994. Rapid identification of gene sequences for transcriptional map assembly by direct cDNA screening of genomic reference libraries. Hum. Mol. Genet. 3: 2019-2023.

Lovett, M., J. Kere, and L.M. Hinton. 1991. Direct selection: A method for the isolation of cDNA encoded by large genomic regions. Proc. Natl. Acad. Sci. 88: $9628-9632$.

Löw, R. and T. Rausch. 1994. Sensitive, nonradioactive Northern blots using alkaline transfer of Total RNA and PCR-amplified biotinylated probes. BioTechniques 17: 1026-1028.

Nadeau, J.H., M.T. Davisson, D.P. Doolittle, P. Grant, A.L. Hillyard, M.R. Kosowsky, and T.H. Roderick. 1992. Comparative map for mice and humans. Mamm. Genome 3: $480-536$.

Parrish, J.E. and D.L. Nelson. 1993. Methods for finding genes: A major rate-limiting step in positional cloning. Genet. Anal. Techniques Applic. 10: 29-41.

Patil, N., A. Peterson, A. Rothman, P.J. de Jong, R.M. Myers, and D.R. Cox. 1994. A high resolution physical map of $2.5 \mathrm{Mbp}$ of the Down syndrome region on chromosome 21. Hum. Mol. Genet. 3: 1811-1817.

Peterson, A., N. Patil, C. Robbins, L. Wang, D.R. Cox, and R.M. Myers. 1994. A transcript map of the Down syndrome critical region on human chromosome 21 . Hum. Mol. Genet. 3: 1735-1742.

Queen, C. and L.J. Korn. 1984. A comprehensive sequence analysis program for the IBM personal computer. Nucleic Acids Res. 12: 581-599.

Reeves, R.H., N.G. Irving, and R.D. Miller. 1993. Mouse chromosome 16. Mamm. Genome 4: S223-S229.

Rommens, J.M., B. Lin, G.B. Hutchinson, S.E. Andrew, Y.P. Goldberg, M.L. Glaves, R. Grabam, V. Lai, J. McArthur, J. Nasir, J. Theilmann, H. McDonald, M. Kalchman, A. Clarke, K. Scharpert, and M.R. Hayden. 1993. A transcription map of the region containing the Huntington disease gene. Hum. Mol. Genet. 2: 901-907.

Rowe, L.B., H.J. Nadeau, R. Turner, N.W. Frankel, V.A. Letts, J.T. Eppig, M.S.H. Ko, S.J. Thurston, and E.H. Birkenmeier. 1994. Maps from two interspecific backcross DNA panels available as a community genetic mapping resource. Mamm. Genome 5: 253-274.

Schaal, H., D. Goldowitz, U.A.O. Heinlein, A. Unterbeck, C. Ruppert, T. Papenbrock, B. Müller-Hill, W. Vielmetter, and W. Wille. 1987. A highly abundant transcript in adult murine cerebellar granule cells contains repetitive sequences homologous to L1. J. Neurosci. 7: 2041-2048.

Sinet, P.-M., D. Theophile, Z. Rahmani, Z. Chettouh, J.-L. Blouin, M. Prieur, B. Noel, and J.-M. Delabar. 1993. Molecular mapping of the Down syndrome phenotype on chromosome 21. Prog. Clin. Biol. Res. 384: 63-86.
Snell, R.G., L.A. Doucette-Stamm, K.M. Gillespie, S.A.M. Taylor, L. Riba, G.P. Bates, M.R. Altherr, M.E. MacDonald, J.F. Gusella, J.J. Wasmuth, H. Lehrach, D.E. Housman, P.S. Harper, and D.J. Shaw. 1993. The isolation of cDNA within the Huntington disease region by hybridization of yeast artificial chromosome to a cDNA library. Hum. Mol. Genet. 2: 305-309.

Su, Y.A., M.J. Trent, X.-Y. Guan, and P.S. Meltzer. 1994. Direct isolation of genes encoded within a homogeneously staining region by chromosome microdissection. Proc. Natl. Acad. Sci. 91: 9121-9125.

Wang, D. and C.L. Smith. 1994. Large-scale structure conservation along the entire long arm of human chromosome 21. Genomics 20: 441-451.

Wei, J.J., S.R. Dlouhy, J.G. Zhu, B. Ghetti, and M.E. Hodes. 1994. Analysis of region-specific library constructed by sequence-independent amplification of microdissected fragments surrounding weaver $(w v)$ gene on mouse chromosome 16. Somatic Cell Mol. Genet. 20: $401-408$.

Yokoi, H., S. Hadano, M. Kogi, X.L. Kang, K. Wakasa, and J.E. Ikeda. 1994. Isolation of expressed sequences encoded by the human $\mathrm{Xq}$ terminal portion using microclone probes generated by laser microdissection. Genomics 20: 404-411.

Yu, J.W., J. Hartz, Y. Xu, R.M. Gemmill, J.R. Korenberg, D. Patterson, and F.T. Kao. 1992. Isolation, characterization, and regional mapping of microclones from HSA21 microdissection library. Am. J. Hum. Genet. 51: $263-272$.

Received February 21, 1996; accepted in revised form June 7, 1996. 


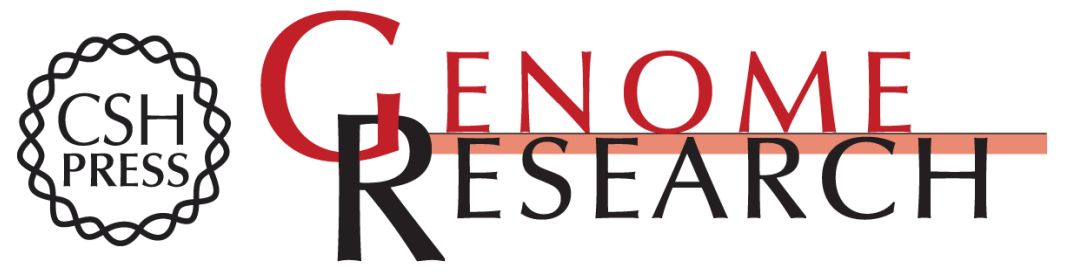

\section{Direct cDNA selection with DNA microdissected from mouse chromosome 16: isolation of novel clones and construction of a partial transcription map of the C3-C4 region.}

J Wei, M E Hodes, Y Wang, et al.

Genome Res. 1996 6: 678-687

Access the most recent version at doi:10.1101/gr.6.8.678

References This article cites 40 articles, 8 of which can be accessed free at:

http://genome.cshlp.org/content/6/8/678.full.html\#ref-list-1

License

Email Alerting

Receive free email alerts when new articles cite this article - sign up in the box at the

Service top right corner of the article or click here.

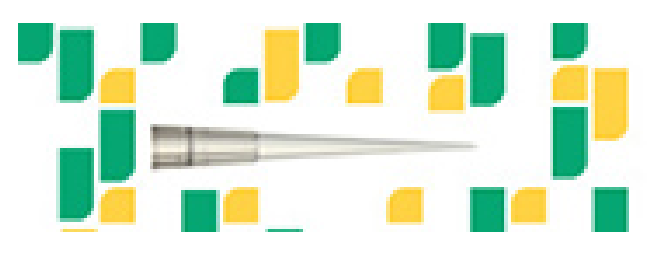

Focused on your science.

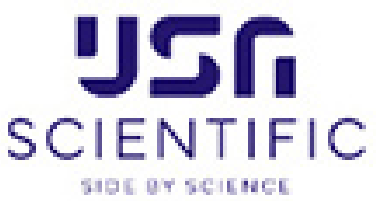

To subscribe to Genome Research go to:

https://genome.cshlp.org/subscriptions 